\title{
Behavior, Milk Yield, and Milk Composition of Machine- and Hand-Milked Murgese Mares
}

\author{
M. Caroprese, ${ }^{\star 1}$ M. Albenzio, ${ }^{*}$ R. Marino, ${ }^{*}$ A. Muscio, ${ }^{*}$ T. Zezza, $\dagger$ and A. Sevi ${ }^{\star}$ \\ *Dipartimento PRIME and Istituto per la Ricerca e le Applicazioni Biotecnologiche per la Sicurezza e la Valorizzazione dei Prodotti Tipici \\ e di Qualità (BIOAGROMED), Università di Foggia, Via Napoli 25, 71100 Foggia, Italy \\ †Dipartimento PROGESA, Università di Bari, Via Amendola 165/A, 70126 Bari, Italy
}

\begin{abstract}
A 25-d trial was performed to assess the effects of machine and hand milking on behavior, and milk yield and composition of mares; the trial involved 8 Murgese mares. Milk yield was higher $(7.69$ vs. $4.91 \mathrm{~kg})$ and milking time was shorter (1.80 vs. $5.40 \mathrm{~min}$ ) in machinemilked than in hand-milked mares. Machine milking of mares also resulted in a greater fat content of milk (1.63\%) than did hand milking (1.06\%). Milking system did not affect casein content, nitrogen fractions, or somatic cell counts. No differences in behavioral activities and in response to humans emerged. Results indicate that machine milking of mares could improve the yield and gross composition of horse milk, without adverse consequences on mare behavior and response to humans.
\end{abstract}

Key words: Murgese mare, milk yield and composition, milking system, behavior

\section{INTRODUCTION}

Mare's milk was traditionally used by nomadic people from the former Union of Soviet Socialist Republics, Mongolia, and Eastern Europe for human nutrition and then for therapeutic purposes in the countries where it was produced (Doreau and Martin-Rosset, 2002). Mare's milk, because of its nutritional characteristics, is a product of great interest not only for human consumption (children, adults, or convalescent consumers), but also as a therapeutic agent and for cosmetic purposes. Recently, there has been increasing interest in mare's milk for human nutrition. In particular, the use of mare's milk has been proposed as a substitute for cow's milk in allergic children, as a substitute for mother's milk for premature newborns, and for other therapeutic purposes (Curadi et al., 2001; Doreau and Martin-Rosset, 2002). In Western Europe, the Haflinger is

Received September 15, 2006

Accepted February 6, 2007.

${ }^{1}$ Corresponding author: m.caroprese@unifg.it considered the main dairy breed (Doreau and MartinRosset, 2002), but the increase in the utilization of mare's milk as a formula for children with allergies could allow the exploitation of a local horse breed such as the Murgese. The Murgese is a light draft and riding horse reared in the area of Murge (Apulia, southern Italy). Murgese horses are usually black, and sometimes gray, and they originated from Oriental-type studs crossed with local mares (Mason, 1996). Murgese horses are a genetic population selected for saddle (Pieragostini et al., 2005) and Murgese mares are not accustomed to a milking routine. Mechanization of many agricultural practices has led to a gradual decline of this breed, which is threatened with extinction at the present time. In the last few years attempts have been made to characterize the milk composition of Murgese mares to promote this local breed (Pinto et al., 2001).

The cisternal compartment of the mare has a very low capacity compared with other dairy animals. Therefore, the use of mares for milk production requires frequent milking, at 2 to $3 \mathrm{~h}$ intervals, and the foals are allowed to suckle the mares for the rest of the day (Doreau and Martin-Rosset, 2002). Previous studies noted that machine milking is more efficient than hand milking of mares, even if the mares are difficult to adapt to the machine-milking procedures after foaling (Le Du, 1986). In mares the milking ejection reflex is related to the expression of maternal behavior. The transition from suckling to milking can be improved by milking the mare with the foal in front of her, or milking one teat while the foal is suckling the other, or offering oats during machine milking ( $\mathrm{Le} \mathrm{Du}, 1986$ ). In contrast, alveolar milk ejection in cows is induced by the oxytocin that is released in response to tactile teat stimulation by the calf, hand, or milking machine (Bruckmaier, 2005).

Success of milking procedures depends on the manageability of mares, which reflects the stockman's ability to impose routine handling of mares and the affinity of the mares to humans (Lansade et al., 2004). Humans can induce fear in animals because of their size and quick movements; improper handling can lead the horse to express dominance behaviors over humans or 
to consider humans as other horses (Jezierski et al., 1999; Rushen et al., 1999).

The aim of the present experiment was to evaluate the effects of machine and hand milking of Murgese mares on milk yield and composition, and on mares' behavior and responses to humans.

\section{MATERIALS AND METHODS}

\section{Animals and Experimental Treatments}

The trial lasted $25 \mathrm{~d}$ and involved 8 Murgese mares (55 \pm 8 DIM), randomly selected from an extensively managed herd in southern Italy (Gioia del Colle, Bari, Italy; $40^{\circ} 48^{\prime} 0^{\prime \prime} \mathrm{N}$ and $16^{\circ} 56^{\prime} 0^{\prime \prime} \mathrm{E}$ ). The mares involved in the experiment were in parity 4 to 6 and had a live weight of $\sim 550 \mathrm{~kg}$. The animals were divided into 2 groups of 4 , balanced in terms of parity and stage of lactation, and subjected to hand or machine milking. Mares were maintained on a natural pasture during the day together with their foals, and kept in individual straw-bedded boxes of $3 \mathrm{~m} \times 3 \mathrm{~m}$ at night. Water was available from troughs at all times. The mares had not previously been subjected to any milking procedures. Both hand- and machine-milking procedures were carried out by milking the udder after manual stimulation to activate the milk ejection reflex, and in the presence of the foal that had been previously prevented from suckling for $3 \mathrm{~h}$ by a muzzle. During each hand- and machine-milking session, mares were given small quantities of concentrate ( $\sim 300 \mathrm{~g}$ per milking). A milking machine for sheep adapted to a mare's udder was used, with a mean vacuum level of $45 \mathrm{kPa}$, a pulsation rate of 120 cycles/min, and a pulsation ratio of $1: 1$. Milk yield and time taken for udder emptying (i.e., milking time) were individually recorded daily for both handand machine-milked mares. Milk yield was recorded by means of graduated measuring cylinders. Individual milk samples from both hand- and machine-milked mares were collected on $\mathrm{d} 1,5,10,15,20$, and 25 of the trial, twice a day at $1000 \mathrm{~h}$ and then at $1300 \mathrm{~h}$. Milk samples, consisting of proportional volumes of the 2 milkings, were individually collected from bucket milk in 200-mL sterile plastic containers after cleaning and disinfecting the teats (70\% ethyl alcohol) and discharging the first streams of foremilk. Both hand and machine milking of the mares were performed in turn by 2 stockmen.

\section{Analysis of Milk}

A total of 96 milk samples were sent to our laboratory by means of transport tankers at $4{ }^{\circ} \mathrm{C}$ and analyzed for their chemical composition. The following measurements were carried out on milk: $\mathrm{pH}$, fat and lactose content using an infrared spectrophotometer (MilkoScan 133B; Foss Electric, Hillerød, Denmark) according to the IDF (1990) standard, and SCC using a Foss Electric Fossomatic 90 cell counter according to the IDF standard (1995). Total N, noncasein nitrogen (NCN), and NPN were determined by standard procedures using the Kjeldahl method (IDF, 1993). Total protein was calculated as total $\mathrm{N} \times 6.38, \mathrm{CN}$ nitrogen was calculated as the difference between total $\mathrm{N}$ and NCN (multiplied by a conversion factor of 6.38), and whey protein as the difference between NCN and NPN (multiplied by a conversion factor of 6.38).

\section{Behavior of the Mares}

At d 5, 15, and 25 the behavioral activities of mares were monitored using a scan sampling procedure, to assess the effect of hand and machine milking on behavioral patterns of the animals. During the pretrial phase, the behavior of each individual mare was monitored daily to test the presence or confirm the absence of behavioral abnormalities. On each observation day, the observer walked slowly in front of each box from a distance of $4 \mathrm{~m}$ and recorded the general behavioral activities of the mares, while trying to be not perceived by the mares. The behavior of each individual mare was video-recorded for $4 \mathrm{~h}$ (from 1100 to $1500 \mathrm{~h}$ ) by a trained person and scan samples were taken every $10 \mathrm{~min}$. At each observation period, the time the mares spent in standing, feeding, and stereotyped pacing was recorded. Neighing, defecating and urinating, litter eating, crib eating, wind sucking, weaving, and kicking are events of short duration; therefore, their frequency of presentation was measured by continuous recording for the whole 4-h period and expressed as the number of events recorded in each activity.

On d 10 and 20, mares were tested for their responses to 5-min open field tests in the presence of a human, who was 1 of the 2 stockmen involved in milking the animals. During the tests, the time spent in proximity to the person (within $2 \mathrm{~m}$ of the human stimulus) and the time spent away from the person (more than $5 \mathrm{~m}$ from the human stimulus) were recorded, and the number of flight attempts was noted.

All procedures were conducted according to the guidelines for the ethical use of animals in applied animal behavior research on the protection of animals used for experimental and other scientific purposes (Sherwin et al., 2003).

\section{Statistical Analysis}

All the variables were tested for normal distribution. Somatic cell count and scan-sampled behavioral data 
Table 1. Least squares means ( \pm SEM) of milk yield, milking time, and milk composition recorded during the 2 daily milk samplings from mares subjected to hand milking and machine milking

\begin{tabular}{|c|c|c|c|c|c|c|}
\hline \multirow[b]{2}{*}{ Variable } & \multirow[b]{2}{*}{$\begin{array}{l}\text { Hand } \\
\text { milking }\end{array}$} & \multirow[b]{2}{*}{$\begin{array}{l}\text { Machine } \\
\text { milking }\end{array}$} & \multirow[b]{2}{*}{ SEM } & \multicolumn{3}{|c|}{ Effect } \\
\hline & & & & $\begin{array}{c}\text { Milking } \\
\text { system (M) }\end{array}$ & $\begin{array}{c}\text { Time of } \\
\text { sampling }(\mathrm{T})\end{array}$ & $\mathrm{M} \times \mathrm{T}$ \\
\hline Milk yield, kg & $4.91^{b}$ & $7.69^{\mathrm{a}}$ & 0.80 & $*$ & $* * *$ & NS \\
\hline Milking time, $\min$ & $5.40^{\mathrm{a}}$ & $1.80^{\mathrm{b}}$ & 0.01 & $* *$ & NS & NS \\
\hline $\mathrm{pH}$ & 7.09 & 7.04 & 0.05 & NS & **** & $\mathrm{NS}$ \\
\hline Fat, $\%$ & $1.06^{\mathrm{b}}$ & $1.63^{\mathrm{a}}$ & 0.09 & $* *$ & NS & NS \\
\hline Lactose, \% & 7.04 & 6.91 & 0.05 & NS & $* * *$ & $* * *$ \\
\hline $\mathrm{CP}, \%$ & 1.85 & 1.99 & 0.09 & NS & $* * *$ & $*$ \\
\hline Noncasein N, \% & 0.17 & 0.18 & 0.01 & NS & **** & NS \\
\hline NPN, \% & 0.03 & 0.03 & 0.01 & NS & **** & $* *$ \\
\hline $\mathrm{CN}, \%$ & 0.77 & 0.82 & 0.08 & NS & $* * *$ & NS \\
\hline Whey protein, \% & 0.89 & 0.94 & 0.07 & NS & **** & NS \\
\hline $\mathrm{SCC}, \log _{10}$ cells $/ \mathrm{mL}$ & 3.81 & 3.88 & 0.07 & NS & $* * *$ & NS \\
\hline
\end{tabular}

${ }^{\mathrm{a}, \mathrm{b}}$ Means within a row with different superscripts differ $(P<0.05)$.

$* P<0.05 ; * * P<0.01 ; * * * P<0.001$.

were evaluated on $\log _{10}$ transformed data to homogenize variance. Milk and behavioral variables were then processed using the GLM procedure of SAS (SAS Institute, 1999), with milking system, time of sampling, and their interaction as sources of variation. Individual animal was nested within each treatment. When significant effects were found $(P<0.05)$, Student's $t$-test was used to locate significant differences between means.

\section{RESULTS AND DISCUSSION}

\section{Milk Yield and Composition}

Results from the present trial showed that the milking system had an effect on the yield and gross composition of mare milk without interfering with the humanmare relationship and mare behavior. Milk yield and composition, and milking times recorded during the 2 daily milk samplings are reported in Table 1 . The machine-milked mares gave higher volumes of milk ( $P$ $<0.05)$ and took less time $(P<0.01)$ for udder emptying than the hand-milked mares. Milk yield decreased starting from $\mathrm{d} 5$ of the trial until the end of the experiment $(P<0.001)$, as an effect of the advancement of lactation. In addition, machine milking of mares resulted in a greater fat content of milk $(P<0.01)$. The milking system did not affect lactose, total protein, and CN contents, nitrogen fractions, or SCC. An effect of time of sampling was found for $\mathrm{pH}, \mathrm{CN}$ content, and SCC $(P<0.001)$ that decreased with the advancement of the study period in both groups, and for whey protein and NCN contents $(P<0.001)$ that increased as the experiment progressed. Time of sampling and the interaction of time of sampling by milking system affected the lactose and protein contents and the NPN fraction, which underwent marked changes through the study period according to different trends in hand- and machine-milked mares. In particular, lactose content increased with the advancement of lactation, being greater in hand-milked than in machine-milked mares, whereas an opposite trend was observed for protein content. The NPN fraction tended to decrease with the progress of lactation. Previous results agree with the observations of Martuzzi et al. (2004) when comparing early lactation with late lactation milk in nursing mares.

Results indicate that there was better milk removal from the udder in the machine-milked mares. In fact, the fat content in the milk from hand-milked mares in the present trial was comparable to that recorded by Pinto et al. (2001) in hand-milked Murgese mares. This indicates that hand milking of mares may result in incomplete emptying of milk from alveoli and galactophorus ducts. It is well known that the cisternal component of the mare's udder has a very low capacity and the main part of milk is alveolar milk. The maximal recovery of milk is obtained by good conditioning of mares to milking routines (Doreau and Martin-Rosset, 2002). Complete milking of the mare's udder requires a good concentration of oxytocin release that can be obtained by the presence of the foal during the milking procedure and the choice of proper working parameters of the machine. Our trial demonstrates that the machine milking of mares may be more efficient than hand milking. The better performance of machine-milked mares could be attributed to the proper choice of the technical parameters of the mechanical milking and to the reduced technical competence of stockmen to hand milking of mares. Indeed, the stockmen performing hand milking were not accustomed to dairy practices, and may have induced disturbances in the mares. Milk ejection can be disturbed by inhibition of oxytocin re- 
Table 2. Least squares means ( \pm SEM) of mares' responses to humans during the open field tests at $d 10$ and 20 in mares subjected to hand or machine milking

\begin{tabular}{lccccccc}
\hline & & & \multicolumn{3}{c}{ Effect } \\
\cline { 5 - 7 } Behavior & $\begin{array}{c}\text { Hand } \\
\text { milking }\end{array}$ & $\begin{array}{c}\text { Machine } \\
\text { milking }\end{array}$ & SEM & $\begin{array}{c}\text { Milking } \\
\text { system (M) }\end{array}$ & $\begin{array}{c}\text { Time of } \\
\text { sampling (T) }\end{array}$ & M $\times$ T \\
\hline Time spent $\leq 2$ m away from human, $\%$ & 21.7 & 22.8 & 8.0 & NS & NS & NS \\
Time spent $>5$ m away from human, \% & 74.5 & 68.3 & 8.3 & NS & NS & NS \\
Flight attempts, n/5 min & 4.9 & 4.1 & 1.9 & NS & NS & NS \\
\hline
\end{tabular}

lease because of emotional stress (Bruckmaier, 2005). In cows, the fear of humans has been shown to reduce milk yield (Rushen et al., 1999). In addition, evidence exists that animals handled by stockmen in an aggressive manner develop a learned nervousness toward humans (Hemsworth et al., 1994, 1995). From this point of view, stockpersons untrained in the hand-milking procedure could have detrimental effects on milk ejection in Murgese mares that are unaccustomed to milking routines.

\section{Behavior of the Mares}

Differences did not emerge in mare responses to human stimulus (Table 2) with respect to milking system. Mares spent more time (3-fold longer) far away from than in proximity to stockpersons ( $71 \mathrm{vs.} 22 \%$ ) and tried to escape from humans with a high frequency ( 4.5 times, on average, over the 5-min duration of open field tests). Thus, the mares' responses to humans indicate the absence of a good relationship between the animals and stockmen, irrespective of the milking system. Previous observations highlighted the limited confidence of mares toward humans. A number of studies have dealt with the effects of aversive or positive handling on animals' welfare and productivity: some authors found that animals subjected to extra handling develop a positive reaction toward the stockmen with beneficial effects on their production compared with animals only subjected to routine handlings (Rushen et al., 1999; Simpson, 2002; Lansade et al., 2004). In lambs, when assessing the effect of gentle handling on the development of the human-animal affinity, no signs of closer familiarity for persons emerged (Caroprese et al., 2006). Accordingly, Mal et al. (1994) found that increased preweaning handling of foals had no effect on their learning ability and manageability.

The observation of mare behavior in boxes (Table 3) did not show differences between groups that could be directly ascribed to the milking treatment: hand-milked mares appeared to be more vigilant as indicated by longer time spent standing alert $(P<0.01)$ and shorter time spent eating $(P<0.05)$ than the machine-milked mares. In fact, as vigilance declines, animals have time available for other activities: many trials found an increase in feeding time as vigilance declined (Treves, $2000)$. On the other hand, the greater number of neighs registered in the machine-milked $(P<0.05)$ compared with the hand-milked mares could be interpreted as a sign of reactivity - a way to attract attention and to relay information about the state of the surrounding environment (Waran, 2001). A previous study cited by

Table 3. Least squares means \pm SEM of behavioral activities recorded in mares subjected to hand milking or machine milking

\begin{tabular}{|c|c|c|c|c|c|c|}
\hline \multirow[b]{2}{*}{ Behavior } & \multirow[b]{2}{*}{$\begin{array}{l}\text { Hand } \\
\text { milking }\end{array}$} & \multirow[b]{2}{*}{$\begin{array}{l}\text { Machine } \\
\text { milking }\end{array}$} & \multirow[b]{2}{*}{ SEM } & \multicolumn{3}{|c|}{ Effect } \\
\hline & & & & $\begin{array}{c}\text { Milking } \\
\text { system (M) }\end{array}$ & $\begin{array}{c}\text { Time of } \\
\text { sampling }(\mathrm{T})\end{array}$ & $\mathrm{M} \times \mathrm{T}$ \\
\hline Standing alert, $\mathrm{s}$ & $4.15^{\mathrm{a}}$ & $4.05^{\mathrm{b}}$ & 0.01 & $* *$ & NS & NS \\
\hline Eating, $\mathrm{s}$ & $0.2^{\mathrm{b}}$ & $0.8^{\mathrm{a}}$ & 0.15 & $*$ & NS & NS \\
\hline Stereotyped pacing, s & 0.88 & 2.07 & 0.47 & NS & NS & NS \\
\hline Neighings, $\mathrm{n}^{1}$ & $0.74^{\mathrm{b}}$ & $1.64^{\mathrm{a}}$ & 0.25 & $*$ & NS & NS \\
\hline Defecating and urinating, $\mathrm{n}$ & 0.11 & 0.01 & 0.05 & NS & NS & NS \\
\hline Bitter eating, $\mathrm{n}$ & 0.13 & 0.62 & 0.22 & NS & NS & NS \\
\hline Crib biting, $\mathrm{n}$ & 0.07 & 0.32 & 0.14 & NS & NS & NS \\
\hline Wind sucking, $\mathrm{n}$ & 0.35 & 0.64 & 0.24 & NS & NS & NS \\
\hline Weaving, $\mathrm{n}$ & 0.06 & 0.41 & 0.2 & NS & NS & NS \\
\hline Kicking, n & 0.01 & 0.39 & 0.17 & NS & NS & NS \\
\hline
\end{tabular}

${ }^{\mathrm{a}, \mathrm{b}}$ Means within a row with different superscripts differ $(P<0.05)$.

${ }^{1} \mathrm{n}=$ number of events for the 4 -h period.

$* P<0.05 ; * * P<0.01$. 
Wolff et al. (1997) reported the whinny as a social search and contact call of horses occurring when social partners are separated. No differences emerged between machine-milked and hand-milked mares for anomalous behaviors.

\section{CONCLUSIONS}

Growing interest in mare's milk for human nutrition could be an important tool for recovery of the Murgese horse breed. Results from the present experiment demonstrated that machine milking of mares was more efficient than hand milking, resulting in a higher yield of fatter milk and in a more rapid udder emptying. The higher production efficiency displayed in machinemilked mares could be because of the proper choice of technical parameters of the mechanical milking and the reduced technical competence of stockmen to hand milking of mares. The open field tests highlighted a poor relationship between mares and stockmen, but the milking system did not influence the behavioral patterns and responses of animals to humans.

\section{ACKNOWLEDGMENTS}

The authors would like to thank Concetta Perilli and Stefano D’Urso for expert technical assistance.

\section{REFERENCES}

Bruckmaier, R. M. 2005. Normal and disturbed milk ejection in dairy cows. Domest. Anim. Endocrinol. 29:268-273.

Caroprese, M., F. Napolitano, M. Albenzio, G. Annicchiarico, A. Muscio, and A. Sevi. 2006. Influence of gentling on lamb immune response and human-lamb interactions. Appl. Anim. Behav. Sci. 99:118-131.

Curadi, M. C., P. G. Giampietro, P. Lucenti, and M. Orlandi. 2001. Use of mare milk in pediatric allergology. Pages 647-649 in Proc. XIV Italian Congress of Associazione Scientifica Produzioni Animali, Firenze, Italy. University of Florence, Italy.

Doreau, M., and W. Martin-Rosset. 2002. Horse. Pages 630-637 in Encyclopedia of Dairy Sciences. Vol. 2. H. Roginski, J. W. Fuquay, and P. F. Fox. MPG Books Ltd., Bodmin, UK.

Hemsworth, P. H., K. Breuer, J. L. Barnett, G. J. Coleman, and L. R. Matthews. 1995. Behavioural response to humans and the productivity of commercial dairy cows. Pages 175-176 in Proc. 29th Int. Congr. of Int. Soc. Appl. Ethol., Exeter, UK. Universities Federation for Animal Welfare, UK.

Hemsworth, P. H., G. J. Coleman, J. L. Barnett, and R. B. Jones. 1994. Behavioural responses to humans and the productivity of commercial broiler chickens. Appl. Anim. Behav. Sci. 41:101-114.

IDF. 1990. Determination of milk fat, protein and lactose contentGuide for the operation of mid-infra-red instruments. IDF Standard 141b. International Dairy Federation, Brussels, Belgium.

IDF. 1993. Determination of nitrogen content. IDF Standard 20B. International Dairy Federation, Brussels, Belgium.

IDF. 1995. Enumeration of somatic cells. IDF Standard 148a. International Dairy Federation, Brussels, Belgium.

Jezierski, T., Z. Jaworski, and A. Gorecka. 1999. Effects of handling on behaviour and heart rate in Konik horses: Comparison of stable and forest reared youngstock. Appl. Anim. Behav. Sci. 62:1-11.

Lansade, L., M. Bertand, X. Biovin, and M. F. Bouissou. 2004. Effects of handling at weaning on manageability and reactivity of foals. Appl. Anim. Behav. Sci. 87:131-149.

Le Du, J. 1986. Mechanical milking of mares. Page 12 in Proc. 37th Annu. Mtg. Eur. Assoc. Anim. Prod., Budapest, Hungary. Eur. Assoc. Anim. Prod., Rome, Italy.

Mal, M. E., C. A. McCall, K. A. Cummins, and M. C. Newland. 1994. Influence of preweaning handling methods on postweaning learning ability and manageability of foals. Appl. Anim. Behav. Sci. 40:187-195.

Martuzzi, F., A. Summer, P. Formaggioni, and P. Mariani. 2004. Milk of Italian saddle and Haflinger nursing mares: Physico-chemical characteristics, nitrogen composition and mineral elements at the end of lactation. Ital. J. Anim. Sci. 3:293-299.

Mason, I. L. 1996. A World Dictionary of Livestock Breeds, Types and Varieties. 4th ed. CABI Publishing, Wallingford, UK.

Pieragostini, E., R. Rizzi, G. Bramante, A. Rosati, G. Perrotta, and A. Caroli. 2005. Genetic Study of Murgese horse from genealogical data and microsatellites. Ital. J. Anim. Sci. 4:197-202.

Pinto, F., M. Faccia, A. Di Summa, and G. Mastrangelo. 2001. Mares' milk: Early result concerning quality and quantity from Murgese and TPR mares. Ital. Equine Sci. J. 2:7-19.

Rushen, J., A. M. B. de Passillé, and L. Munksgaard. 1999. Fear of people by cows and effects on milk yield, behavior and heart rate at milking. J. Dairy Sci. 82:720-727.

SAS Institute. 1999. SAS User's Guide. Statistics, Version 8.1 ed. SAS Institute, Inc., Cary, NC.

Sherwin, C. M., S. B. Christiansen, I. J. Duncan, H. Erhard, D. Lay, J. Mench, C. O'Connor, and C. Petherick. 2003. Guidelines for the ethical use of animals in applied animal behaviour research. Appl. Anim. Behav. Sci. 81:291-305.

Simpson, B. S. 2002. Neonatal foal handling. Appl. Anim. Behav. Sci. 78:303-317.

Treves, A. 2000. Theory and method in studies of vigilance and aggregation. Anim. Behav. 60:711-722.

Waran, N. K. 2001. The social behaviour of horses. Pages 247-274 in Social Behaviour in farm animals. L. J. Keeling and H. W. Gonyou, ed. CABI Publishing, Wallingford, UK.

Wolff, A., M. Hausberger, and N. Le Scolan. 1997. Experimental tests to assess emotionality in horses. Behav. Processes 40:209-221. 